\title{
Smelling Disease and Death in the Antwerp Church of Our Lady, c. 1450-1559
}

\section{Wendy WaUters}

Wendy Wauters is a PhD candidate in Art History (KU Leuven) participating in the Brain-Belspo project Ornamenta sacra led by KU Leuven, UCLouvain, and KIK-IRPA Brussels. After being awarded the Olbrechts Prize for her master's thesis Een oven vol van menig hoofd en zotten bol, she is now working on a dissertation on the sensory dimension of paraliturgical objects and the spatial experience of the early modern churchgoer, under the supervision of Barbara Baert. Wauters's recent publications include 'The Stirring of the Religious Soundscape', in Christian Discourses of the Holy and the Sacred from the 15th to the 17th Century (2020), and several entries for the exhibition catalogue The World of Bruegel in Black and White (2019).

\begin{abstract}
Early modern societies were pervaded by smells and odours, but few traces have survived that offer a glimpse of the olfactory experience. This essay reconstructs this lost early modern 'smellscape', focusing on the smell of disease and death in the late medieval Antwerp Church of Our Lady (c. 1450-1559). Bustling cathedrals and parish churches could be a minefield of life-threatening odours, as there was a strong interaction between externally perceived body odour and a person's inner sweetness. Through devotional objects and liturgical rituals, however, it was possible to protect oneself from the stench of both living and dead parishioners. Exemplary markers for the shared discourse of smell on a medical and spiritual level were aromatic prayer beads and purifying incense.
\end{abstract}

Keywords: smellscape, miasmata, spatial experience, parish church, iconology, Antwerp Church of Our Lady

DOI 10.51750/emlc10006 - URL: http://www.emlc-journal.org

Publisher: Stichting EMLC

Copyright: The Author(s). This work is licensed under a Creative Commons Attribution-NonCommercial 4.0 International License. 


\title{
Smelling Disease and Death in the Antwerp Church of Our Lady, c. 1450-1559
}

\author{
Wendy WaUters
}

In the late medieval Low Countries, memento mori pendants served to remind believers of their personal mortality while cautioning them against becoming overly attached to fleeting earthly possessions and outward appearances. The idea of the memento mori - literally 'remember that you die' - was present as a theme in texts and imagery throughout the Netherlands, Germany, and France. Death was presented as the great leveller, indifferent to physical beauty or social class. These pendants usually featured a skull juxtaposed with a portrait depicting more individual features, and could be made up of simple ivory beads depicting a single skull to intricate carvings showing, for example, a lavishly dressed young man on one side and a rotting cadaver on the other. ${ }^{1}$ A memento mori pendant worn on the end of a rosary not only conveyed the idea of impending death, but also an additional aspect: a feeling of control. Praying for the salvation of one's own soul and the souls of others was a way to exert power over their destiny. The more prayers were said on its behalf, the faster a soul could escape purgatory. ${ }^{2}$

A passing mention in the condition report of a memento mori pendant in England (fig. 1, left), is the starting point of this essay: 'Various areas of the object, such as the nose, have particularly smooth surfaces, which indicate where it would have been rubbed by the owner during private devotion. ${ }^{3}$ When viewed in profile, it is clear how intensely the nose of the young lady has been abraded in comparison to the features of the skeleton on the opposite side. In fact, that side shows no signs of wear at all, as if its owners fastidiously avoided making contact with the repulsive representation of death. This is by no means an isolated case. ${ }^{4}$ Many pendants from the period $1520-1530$

1 Perkinson, 'The Ivory Mirror', 29, 49-50. On the emergence and dissemination of this motif, see esp. 26-34. On amber pendants, see King, 'The Beads', 155. I am grateful to my supervisor Barbara Baert and Illuminare Centre for Medieval and Renaissance Art (KU Leuven) for their help and support. Special thanks go to Violet Soen, Louise Deschryver, Isabel Casteels, and the reviewers for their time and insightful comments on this article. Unless otherwise noted, all translations are by Kris Thielemans. This article is published with the generous support of the Universitaire Stichting of Belgium.

2 Perkinson, 'The Ivory Mirror', 26-28.

3 'Memento Mori Pendant'; Carter, 'Memento Mori'.

4 These findings are based on photographic material and available condition reports. For a compilation of a significant portion of preserved pendants, see: 'Gothic Ivories'. This is consistent with a wider tradition, such as rubbing Christ's wound in manuscripts. 


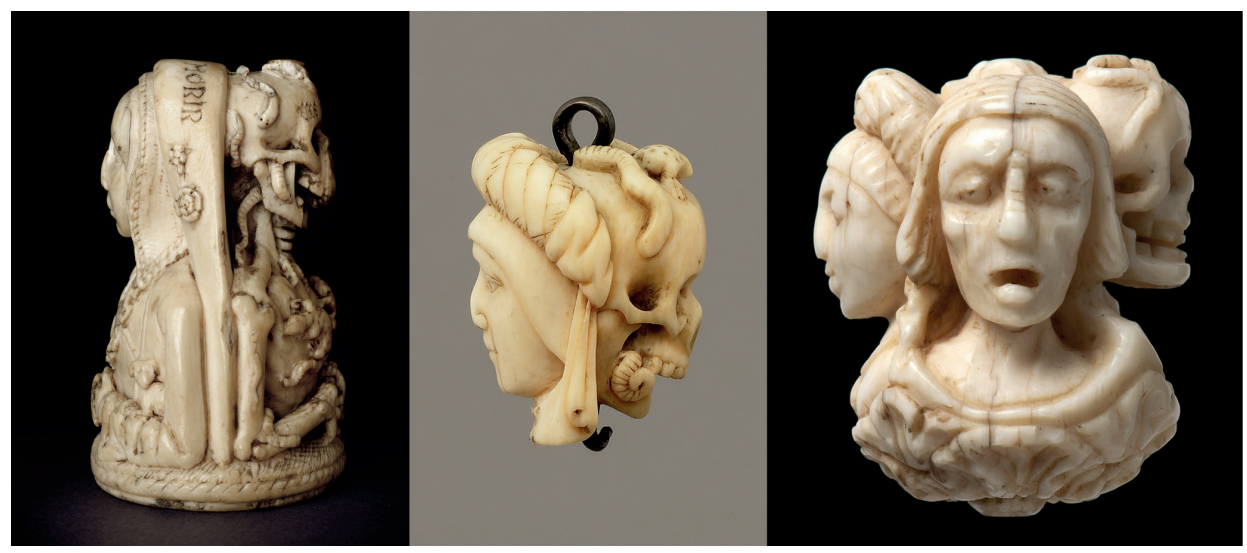

Fig. 1 Left: Memento mori pendant, c. 1500, ivory, 7,6 cm (h), London, Ranger's House. Middle: Memento mori pendant, 1500-1550, ivory, 3,o cm (h), Antwerp, Museum Mayer van den Bergh. Right: Pendant with four faces, $c$. 1520-1530 or 1600, ivory, 4,o x 3,2 cm, Stuttgart, Landesmuseum Württemberg.

in the Southern Netherlands show significant wear to the olfactory organ on the youthful side (fig. 1). ${ }^{5}$ Of course, it should also be considered that the noses show the most wear simply because they protrude the most. There are pendants on which the entire healthy face has eroded while the cadaver remains untouched (fig. 2). ${ }^{6}$ Why did the owners of these pendants rub their noses so intensely? Offering a rare glimpse of the lived religion of the late medieval period, these pendants also hint at one of the most important, but also evasive aspects of religious sensory experiences: the importance of smell in devotion.

Religious art produced in the Southern Netherlands was heavily influenced by olfactory theories and practices. In these, the sweet-smelling kingdom of heaven was posited in direct opposition to the stinking ubiquity of disease, decay, and death. ${ }^{7}$ Aromas that were universally perceived to be pleasant were nothing less than reflections of the divine or of paradise, and various other forms of holiness, but a whiff of bitter myrrh was enough to conjure up thoughts of Christ's suffering body. ${ }^{8}$ Reindert Falkenburg has already drawn attention to the many sensual garden allegories that adorned texts and imagery from the fifteenth to the start of the sixteenth century, and Paul Vandenbroeck has captivatingly

5 See for more examples: Pendant, 1500-1550, Antwerp, Museum Mayer van den Bergh, inv. no. 453; Pendant, 1520-1530, London, Victoria and Albert Museum, inv. no. 2149-1855; Pendant, early sixteenth century, Stuttgart, Landesmuseum Württemberg, inv. no. Kk Braun-Blau 15; Pendant, early sixteenth century, Cologne, Museum Schnütgen, inv. nos. B 130 and B 133.

6 Pendant, late fifteenth century, Cologne, Museum Schnütgen, inv. no. B 161. The beads are currently part of a seventeenth-century pastiche rosary: Perkinson, 'The Ivory Mirror', 51. Around half of the pendants examined from the first half of the sixteenth century show no visible signs of rubbing. See for example: Pendant, 1504, Braunschweig, Herzog Anton-Ulrich Museum, inv. no. elf 16; Pendant, 1500-1525, Toronto, Art Gallery of Ontario, The Thomson Collection, inv. no. 29272; Pendant, sixteenth century, Cologne, Museum Schnütgen, inv. no. B 131.

7 Camporesi, Het onvergankelijke vlees, 189.

8 Verbeek and Van Campen, 'Inhaling Memories', 141. 

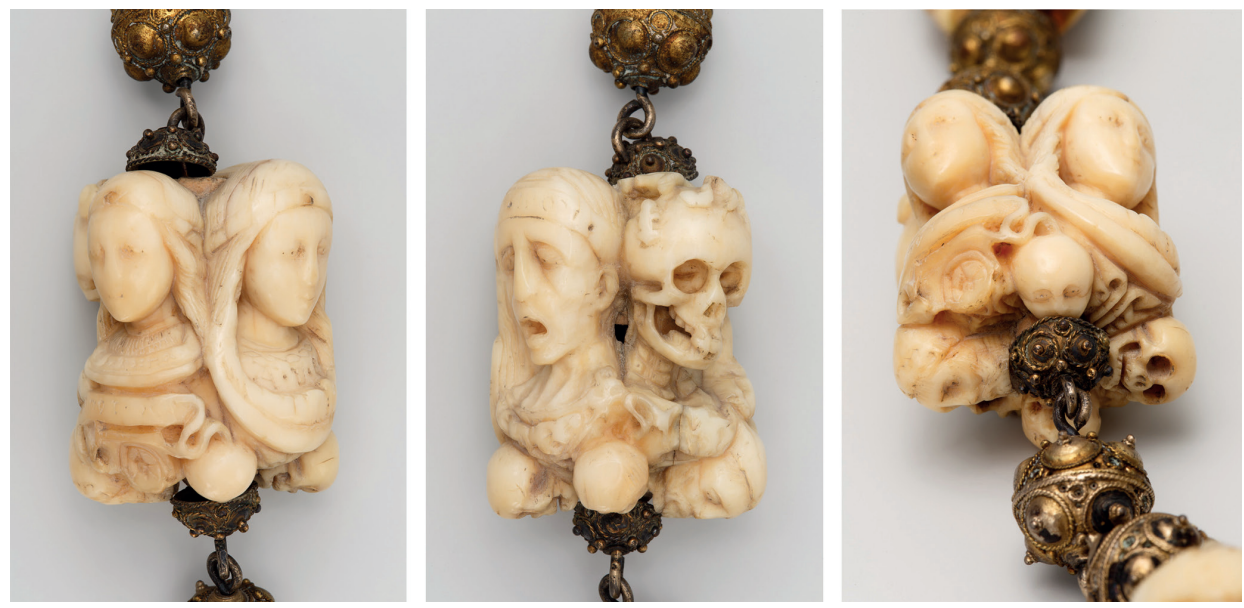

Fig. 2 Chaplet bead, 1520-1530, ivory and silver, Cologne, Museum Schnütgen.

revived interest in the olfactory dimensions of the 'Enclosed Gardens' of the Hospital Sisters in Mechelen in the sixteenth century. ${ }^{9}$

The parish churches in which such objects circulated had a highly volatile smellscape. The stench of both living and dead parishioners and the olfactory protection one could rely on for physical and spiritual well-being were part of the daily dimensions of church life. ${ }^{10}$ When examined within their physiological and spatial context, these devotional objects acquire new layers of meaning. This essay will reconstruct the wider smellscape of death and disease in a late medieval parish and church, namely that of Our Lady in the city of Antwerp, by focusing on its impact on material and art historical record. ${ }^{11}$ The period under review begins in the mid-fifteenth century, when the church grew exponentially, and ends with the reorganisation of the bishoprics of the Low Countries in 1559, when it became the cathedral of a newly erected bishopric. The essay analyses the religious olfactory imagery, the smellscapes of the late medieval church, and especially the effect of stinking corpses and purifying incense in and beyond the church building. As such, the essay shows how devotional objects were used to reconfigure the smellscape of death and disease in the church of Our Lady.

9 Falkenburg, The Fruit of Devotion; Vandenbroeck (ed.), Hooglied, 91-117; Baert, Late Medieval Enclosed Gardens. For a recent archaeobotanical study on realism versus symbolism of flora in publicly accessible religious art, see Sillasoo, 'Medieval Plant Depictions'. Depictions and installations overloaded with flora were not only displayed within the walls of churches or cloisters but were also popular with an affluent lay public. Their presence was not restricted to within cloister walls, but extended into the household chapels and Wunderkammer of the wealthy middle class: Baert and Iterbeke, 'Revisiting the Enclosed Gardens', 5.

10 Soen and Van Bruaene, 'Sacrale ruimte'.

11 For a European contextualisation of religious material culture during the late Middle Ages, see Bynum, Christian Materiality. 


\section{Olfactory Imagery}

From their baptism onwards, through olfactory practices and ideas, Catholics distinguished themselves from adherents of other confessions by smelling sweetly of virtuousness. During the ritual, the priest would touch the infant's nose and speak the words in odorem suavitatis ('to a pleasant/sweet smell'), in order to expel the stench of $\sin .{ }^{12}$ But life was a continuous struggle against great and small temptations. The acquired stench of sinfulness had to be repeatedly washed away, which required the performance of virtuous acts such as attending church. It was common practice to employ incense up to seven times during one solemn Mass. ${ }^{13}$ Although it is impossible to know with certainty how many sung and low Masses were celebrated each day in the Antwerp church, we can produce a rough estimate based on the number of communion wafers that were consumed. Between 1465 and 1477, 22,00o large hosts were used by priests associated with the church (for the elevation). Assuming that each one was consumed, and that each priest officiated around three hundred Masses per year, it is estimated that there were fifty to seventy priests who, combined, officiated over some sixty Masses per day. ${ }^{14}$ The continuous increase in the number of celebrations led to the ritual of low Masses being simplified to its most basic form. The structure of the solemn Mass continued to be the norm and was retained as the template from which there could be deviations or certain actions eliminated. In the shortened version, the priest would fulfil the roles of deacon and subdeacon, only one acolyte sang, and the censing and the kiss of peace could be skipped. ${ }^{15}$ In 1533 , the church housed (depending on the source) 'at least fifty-seven' or 'more than seventy' side altars, which could host devotional Masses simultaneously (fig. 3). ${ }^{16}$ Even with simplified low

12 Classen, 'The Breath of God', 380. On the hermeneutical interpretation of the baptism ritual and olfactory imagery, see Albert, Odeurs de sainteté. Milner, The Senses, 136, describes a different version of the procedure: the priest commands the nostrils to take in sweet smells, and his sweet-smelling words (the 'incense of his breath') drive out any evil spirits via the right ear. Erasmus discussed his views on this expression in his Annotationes: Erasmus, Annotationes, fol. 797.

13 For a list of those occasions during Mass in the Church of Our Lady, see the 1506 founding act for the sung Mass in Antwerp on Thursdays (a sacramental Mass, corresponding to the Sunday High Mass): Van Den Nieuwenhuizen, 'De koralen, de zangers', 66-68. A historical reconstruction of the occasions on which incense was used (Romanesque Mass, France) is available in Gauthier, L'encens, 126-130. On the genesis of its usage from a theological point of view, see Pfeifer, Der Weihrauch, 55-137. See also Atchley, A History of the Use of Incense, 234-268.

14 Prims, Geschiedenis van Antwerpen, vI, 145. Van Den Nieuwenhuizen, Kapelaniewezen en kapelanen, 300302, calculates the number of chantries at the Church of Our Lady in 1477 as follows: $14,768 / 365=$ c. 40 per day. For the methodological pitfalls and an excellent qualitative interpretation of the quantities of wafers and wine, see Suykerbuyk, The Matter of Piety, I, 226-235.

15 Fortescue, 'Liturgy of the Mass'; Duffy, Stripping of the Altars, 123-124.

16 The number varies depending on the study. Nieuwdorp, 'Het kunstpatrimonium', 170, claims there were more than seventy altars around 1500 , though his source remains unclear. Guicciardini describes the destruction of fifty-seven altars in a fire: Guicciardini, Beschrijvinghe, 63. Mertens and Torfs, Geschiedenis van Antwerpen, III, 104, cite a chronicle on the iconoclasm which records the destruction of seventy altars in 1566 . Note that the term 'altar' is problematic: it is not entirely clear if chroniclers meant an altar in the strictest sense of the word (i.e., where a Mass is celebrated), or more broadly to mean 'all tables that were utilised for religious activities', which would include altars used for the display of relics and sculptures of saints without being used to celebrate Mass: Mertens and Torfs, Geschiedenis van Antwerpen, viII, 251. My ongoing doctoral research attempts to create a hypothetical reconstruction of the locations. 


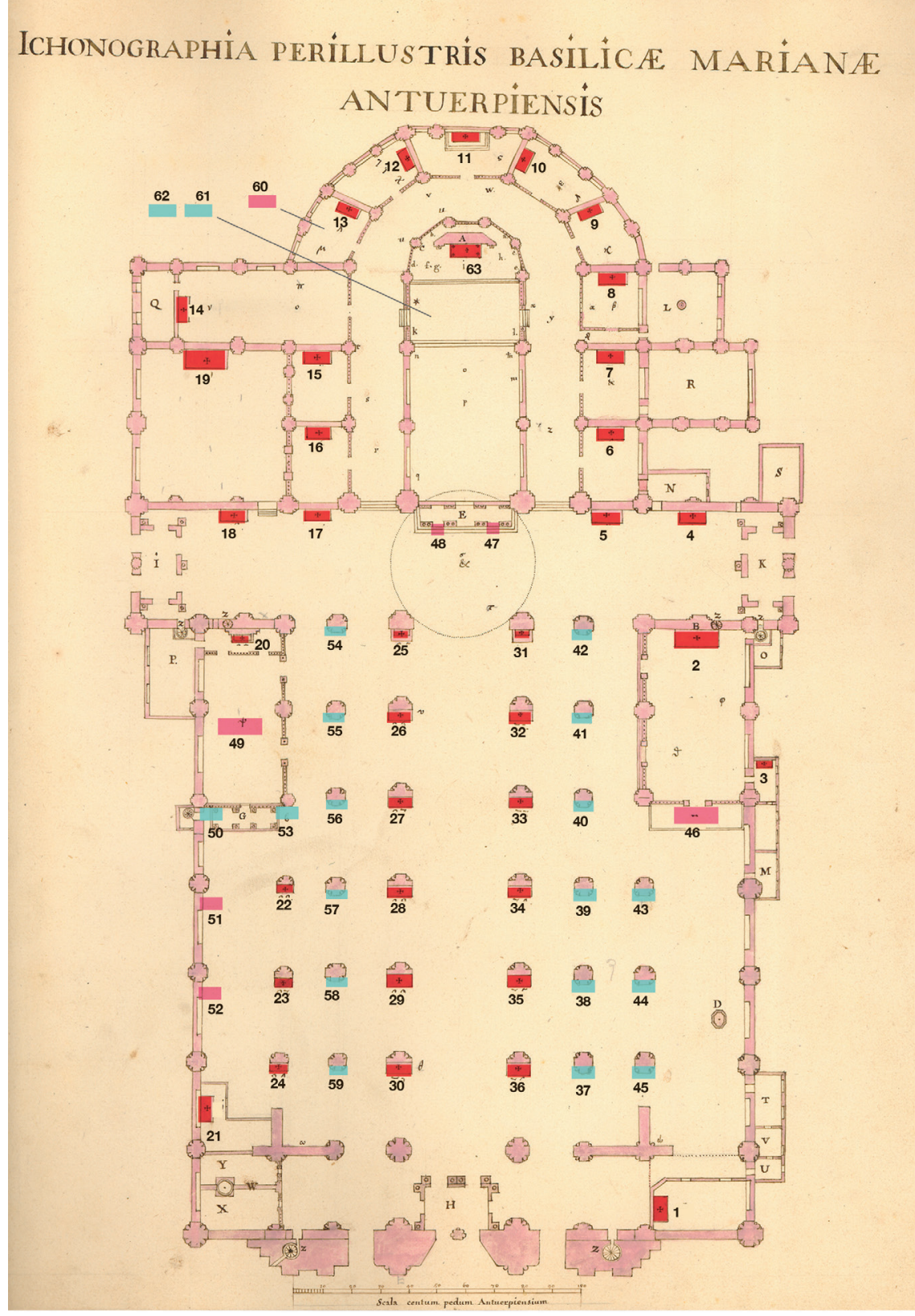

Fig. 3 Hypothetical reconstruction of the altar locations in the Antwerp Church of Our Lady in the sixteenth century, based on the oldest known floor plan of the church. Red: confirmed altar locations; pink: altar locations not indicated on the floor plan; blue: possible altar locations. Ichonographia Perillustris Basilicae Marianae Antuerpiensis, drawing, $57 \times 43 \mathrm{~cm}$, in: Petrus Henricus Goos, 2 vols., Encronologium episcoporum, 1695-1719, II, fol. 95, Antwerp, Erfgoedbibliotheek Hendrik Conscience. Visualisation by the author. 
Masses, then, the church provided a smorgasbord of fragrant side altars for parishioners throughout the day. After exiting the church, they would emanate a pleasing odour that was directly associated with virtue. ${ }^{17}$ In addition, any stigmatising body odour would be dispelled in the sweetly aromatic haze. Internal and external fragrances were intermingled, so there would be an olfactory transformation on the physical plane to match the spiritual. The aroma of the ubiquitous incense lingered in the clothing of worshippers.

The counterpart was the stench of sin. On the one hand, people were averse to persons or objects that reeked unpleasantly, but on the other they ascribed negative olfactory characteristics to social groups or individuals who were considered to be undesirable. ${ }^{18}$ The stench emanated by the adherents of other confessions was employed as a topos by both Catholics and Protestants. In her artful refrains, the sixteenth-century Antwerp schoolmistress and poet Anna Bijns sighed: 'Too long you tolerated our wicked ways, expecting improvement, but it worsens every day. The stench of our sins pollutes the air. ${ }^{19}$ Social outcasts such as witches were known to secrete a disgusting, animalistic smell, and there was even a term specifically for the stink of Jews, the so-called foetor judaeicus. ${ }^{20}$ The active use of olfactory signalling in order to make or break someone's reputation is evident in the public burning of the Lollard priest Richard Wyche and the ensuing turmoil that occurred in London in 1440. Tower Hill, where the burning took place, was soon transformed into a shrine attracting crowds of pilgrims. Wyche's ashes apparently produced the divine odour of incense and were distributed across the country as sought-after relics. London's authorities retaliated by situating a dunghill at the newly sacred location. ${ }^{21} \mathrm{~A}$ foul smell was not only a sure sign of sinfulness but could also be used as a gross insult. ${ }^{22}$

A late medieval image depicting this idea can be found among the illustrations of the Holkham Bible (c. 1327-1335) (fig. 4). Christ accuses those who loudly proclaim their own devotion of hypocrisy. They reek like a tomb that on the outside boasts opulent decorations but whose inside is nothing but rotting corpses. The accompanying miniature shows a church building in which a worshipper seated next to a tombstone holds his nose because of the pervasive smell of death. ${ }^{23}$ The text is derived from the Historia Scholastica (1169-1175) by Petrus Comestor, who based his work on the Gospel of Matthew: 'Woe to you, teachers of the law and Pharisees, you hypocrites! You are like whitewashed tombs, which look beautiful on the outside but on the inside are full of the bones of the dead and everything unclean' (Matt 23:27). ${ }^{24}$

17 Durandus explained that censing the priest - just before the reading of the Gospel - conferred on him the aroma of 'a good reputation', which he must project: Durand, Rationale, 199-200, 206.

18 Classen, 'The Odor of the Other', 135; Largey and Watson, 'The Sociology of Odors', 1025.

19 Bijns, Refereinen, 419: 'Ghij hebt ons boosheyt soo lange verdragen, Beternisse verwacht; maer targert alle dagen, Den stanck onser sonden die lucht bevleckt.'

20 Largey and Watson, 'The Sociology of Odors', 1022.

21 Dugan, The Ephemeral History, 24-25; Woolgar, 'The Medieval Senses'; Thomson, 'Wyche, Richard'.

22 Being accused of having a bad breath was considered to be particularly humiliating: Middelnederlandsch Woordenboek, entry 'stinken'.

23 Woolgar, The Senses, 123, fig. 45.

24 St. Gallen, Stiftsbibliothek, Cod. Sang. 547, Petrus Comestor, Historia Scholastica, Historia Evangelica, cap. cxxxiv: 'Item: Vae vobis, qui similes estis sepulcris dealbatis, quae plena sunt omni spurcitia.' 


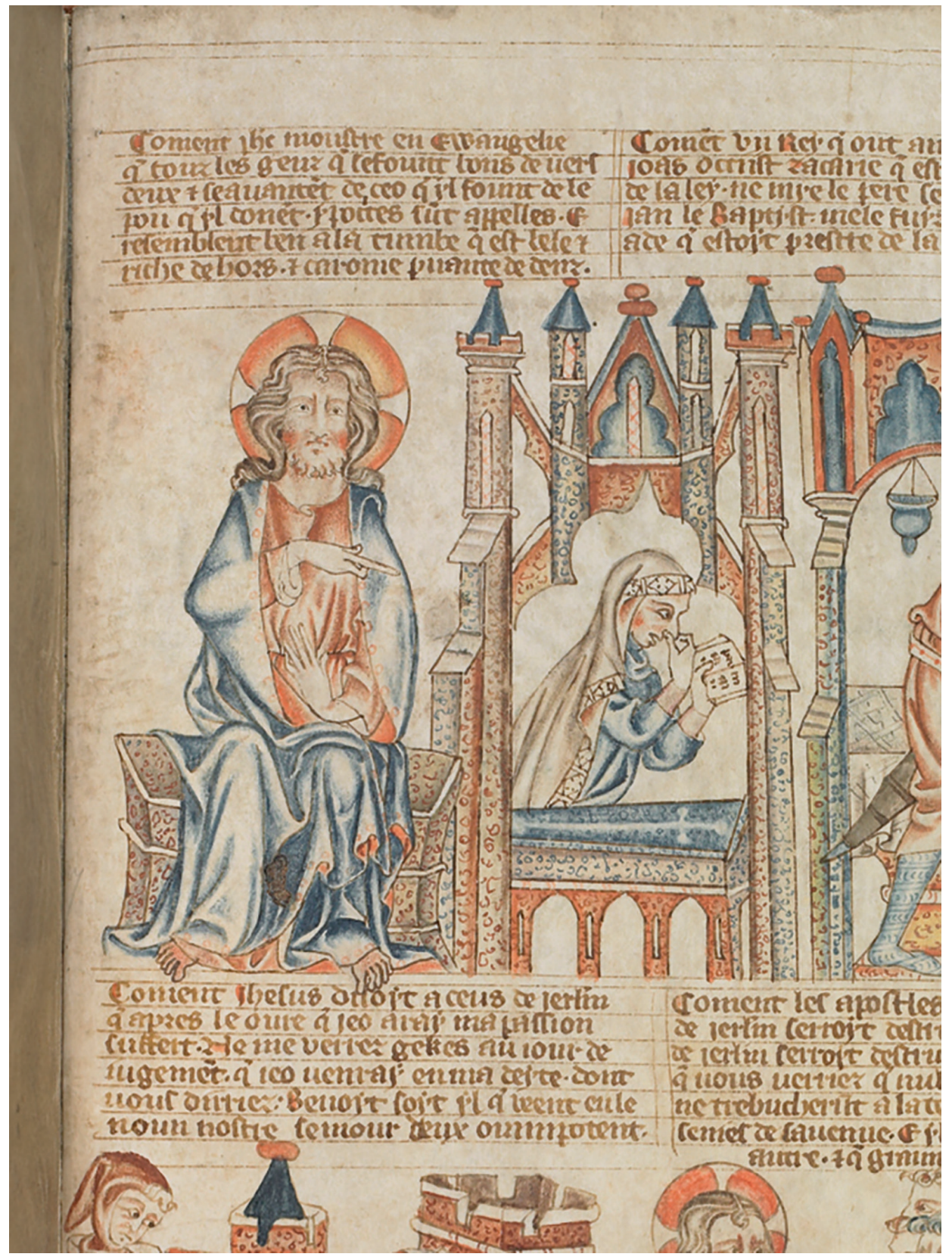

Fig. 4 Christ indicates the nature of hypocrites, parchment codex, in Holkham Bible Picture Book, c. 1327-35, fol. 39r, London, British Library. 
The olfactory experience was thus characterised by a structured hierarchical system and the interplay between the external perception of body odour and inner spiritual sweetness. ${ }^{25}$ Only a sincere conversion to the true faith could dispel all physical and spiritual malodorousness. It was even possible for God to supersede the earthly stench of a deteriorating or dead body with the spiritual sweetness of the devout Catholic. ${ }^{26}$ Concurrent with the success of late medieval garden allegories, Roman Catholicism saw a peak in experiences of this odour of sanctity (osmogenesia). The phenomenon affected only the dying bodies of the most virtuous believers. Female mystics, who continuously subjected their emaciated bodies to neglect and deprivation, were especially likely to be counted among the lucky few. Their mortal coil was found worthy enough to produce the sweet perfume of sanctity. ${ }^{27}$

\section{Smelling Disease}

What was the day-to-day smellscape in which this hierarchical olfactory system functioned? In the Antwerp Church of Our Lady, some altars were exceptional hotbeds of contagion and death. Relics that promised to deliver healing and good luck attracted droves of pilgrims, penitents, and those in need of aid. ${ }^{28}$ The public presentations of the Holy Foreskin, the most famous of the local relics, would have drawn particularly impressive crowds of believers. The most lucrative cult object, however, was the miraculous statue of Onze-Lieve-Vrouw op 't Stokske (Our Beloved Lady of the Pole). This statue quickly attracted great numbers of ailing and grateful patients, with a peak in devotional gifts in the 1490 s and a decline from the early 1520 s. ${ }^{29}$ Of course, the physical condition of the patients was less than ideal. None of the suffering or sick were without stinking wounds, infections, or festering boils. The ingredients that were added to some medicinal oils, homemade salves, pomanders, and balsams also contributed to the lurid aroma. In their frantic search for healing or pain relief, people put their faith in all sorts of remedies. 'Secret ingredients' (geheimmiddelen) such as bat droppings, ox manure, human urine, smegma, rotting sperm, and children's blood were applied to suffering bodies as late as the eighteenth century. ${ }^{30}$

25 In the West, body odours were perceived as intrinsic essences being revealed. Associating body odour with moral qualities continues to this day (be it conscious or not): Largey and Watson, 'The Sociology of Odors', 1024; Classen, Howes, and Synnott, Aroma, 4; Synnott, The Body Social, 183; Classen, 'The Odor of the Other', 134; Baum, 'From Incense', 329-330; Milner, The Senses, 32.

26 Classen, Howes, and Synnott, Aroma, 52-53; Baum, 'From Incense', 328-329. Even the critical bishop Hovius trusted in this perfume for the identification of authentic relics: Put and Harline, Verloren schapen, 161.

27 For a broader context, see Classen, 'The Breath of God', 379, 384; McBride, 'The Odour of Sanctity'. On collective delusion as concretisation of sacrality and for a contextualisation of healing, fragrant corpse juices (liqueur), see Camporesi, Het onvergankelijke vlees, 17-30, esp. 22-23.

28 On the relics in the cathedral, see Vroom, De Onze-Lieve-Vrouwekerk, 49.

29 Vroom, De Onze-Lieve-Vrouwekerk, 51, 59-60; Philippen, Le culte de Notre-Dame, 17, 20, 31-32; Marnef, Antwerpen in de tijd van de Reformatie, 83-86; Suykerbuyk, The Matter of Piety, I, 163-164.

30 Camporesi, Het onvergankelijke vlees, 175-178. See also several recipes in Braekman (ed.), Dat batement, 97, 102 . 
Odours signalling disease were understood within the paradigm of the four bodily fluids, or humours: phlegm, blood, yellow bile, and black bile. An imbalance in the humours was believed to be the cause of physical and mental disorders and could even lead to death. The main culprit causing such disharmony was airborne rotting organic material, known as miasmata. Marshlands, musty rooms, and sick wards were to be avoided, and poor air circulation was believed to be as hazardous as stagnant water. ${ }^{31}$ The deeper technical understanding of these theories was mostly reserved for the learned classes who applied their knowledge professionally, but the basic principles were widely known to the public. ${ }^{32}$ People were not powerless against the onslaught of miasmata, as they could protect themselves through the use of certain aromas. Pleasant smells did not simply mask the stench of disease and death, they actually inhibited infection by keeping dangerous airborne particles at bay. It was also understood by medical science at the time that the nose provided direct access to the brain, so breathing in healthy air was considered more efficacious than swallowing medicine which then had to traverse much of the body. ${ }^{33}$ Because people were to some extent able to control the atmosphere around them, numerous treatises were written on how to manage air quality. An oft-used method was fumigation, which involved the burning of aromatic spices in public spaces, on the streets, or at home. Additional ways of suppressing foul air included carrying spices (for example in pomanders), wearing strong perfumes, and the lighting of bonfires. The keeping of birds as pets was also recommended, as the flapping of their wings would help circulate the air. ${ }^{34}$

The fear of miasmata was most pronounced during plague outbreaks. As in other cities with an expanding population, these were quite common in late medieval Antwerp. ${ }^{35}$ Countermeasures focused mainly on combating foul air emanating from corpses and in the breath of plague victims. Just about any pungent odour was considered beneficial, and during an outbreak, most sources strongly advised against going out in public without olfactory protection. ${ }^{36}$ There were numerous publications in circulation providing medical guidance in those uncertain times. The widely disseminated recipe book Een nieuwe tractaet ghenaemt dat Batement van recepten (Antwerp 1549), for example, was one of many containing instructions for making a pomander that offered protection against the plague. ${ }^{37}$ The Fasciculus medicinae (Venice 1491), one of the most successful late medieval medical treatises, also featured various olfactory remedies. A later edition, produced in Antwerp in 1512, was the first illustrated medical book to appear in the Netherlands. ${ }^{38}$

31 Corbin, The Foul and the Fragrant, 13; Jansen-Sieben, 'Ziektebeeld en behandeling', 41; Camporesi, Het onvergankelijke vlees, 248-249.

32 Sullivan and Wear, 'Materiality, Nature and the Body', 141-143.

33 Classen, Howes, and Synnott, Aroma, 60-61; Milner, The Senses, 31.

34 Blancou, 'History of Disinfection', 35-36; Rombough, 'Through Thick and Thin'; Corbin, The Foul and the Fragrant, 64; Rubens, 'Wijzigende concepten', 59; De Gelder, 'In God's ban geslagen?', 59. On home remedies for all sorts of maladies, including chewing or burning herbs, see Camporesi, Het onvergankelijke vlees, 204-205.

35 The worst outbreaks occurred in 1436-1439, 1456-1459, 1481-1485, 1490, 1504, 1512-1516, 1529, 1534, 1546, and 1571. See De Commer, 'Hygiëne en gezondheidszorg', 38-39; Prims, Geschiedenis van Antwerpen, viI, 148; Lowagie, Par Desperacion, 211.

36 Classen, Howes, and Synnott, Aroma, 60; Baum, Sensory Perception, 128.

37 Braekman (ed.), Dat batement, 94.

38 Coppens, "'For the Benefit"', 168. The compilation was made by Johannes de Ketham and covers an assortment of medical knowledge, from anatomical models to plague treatments. 

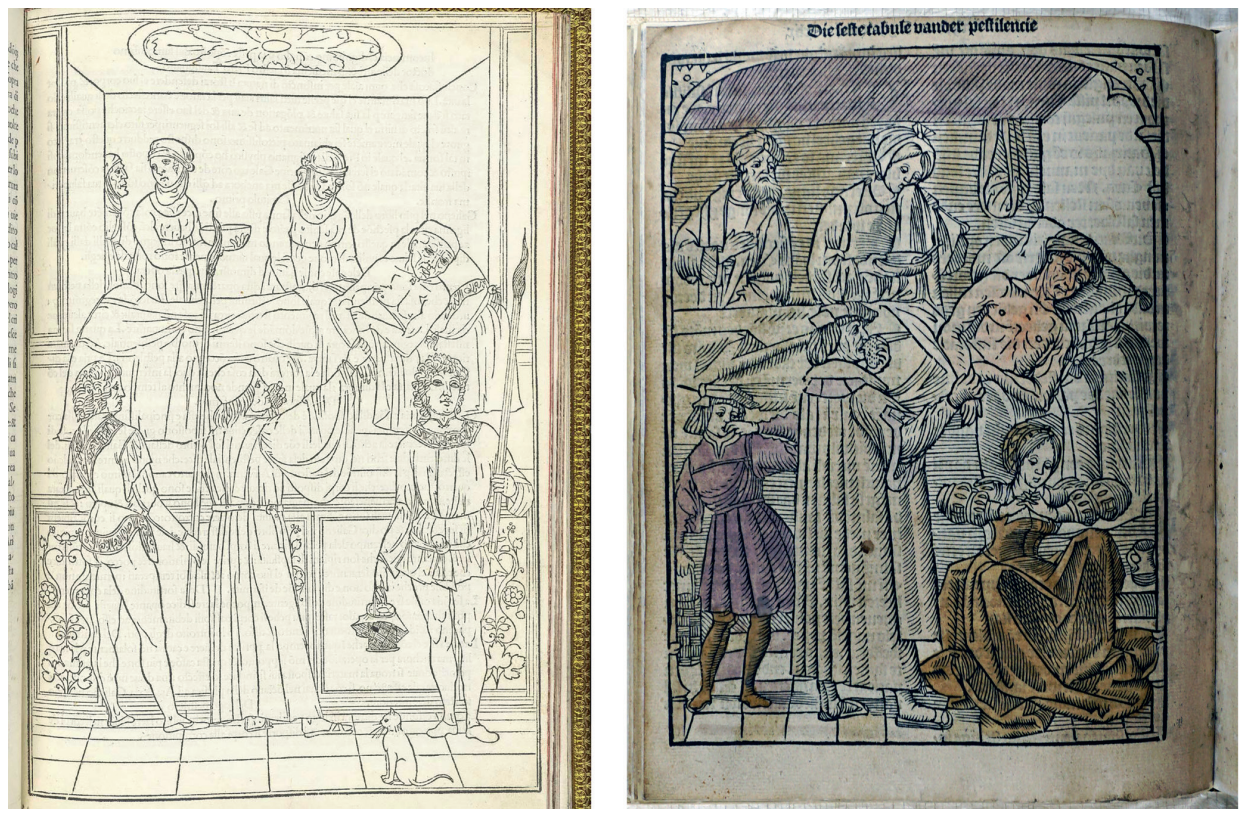

Fig. 5 Left: Anonymous Italian artist, Doctor Visiting a Plague Patient, woodcut, 26,3 $x$ 16,4 cm, in: Johannes de Ketham, Fasiculo de medicina, Venice 1494, fol. e2r, Bethesda, MA, U.S. National Library of Medicine. Right: Anonymous, Doctor Visiting a Plague Patient, coloured woodcut, in: Johannes de Ketham, Fasciculus medicine, trans. Petrus Antonianus, Antwerp 1512, fol. h4v, Leuven, KU Leuven, Central Library.

A woodcut illustrating the chapter on the plague features a doctor paying a visit to a wealthy patient and serves as a compendium of miasmata countermeasures (fig. 5). As the doctor takes the pulse of his bed-ridden patient, he holds a pomander with laudanum up to his own face to dispel the foul air. This method was extremely popular as there were endless variations in the available scents, and ingredients were customisable depending on the financial resources of the buyer. ${ }^{39}$ The woman carrying a bowl of soup is also protecting her nose with a scented cloth. The young assistant in the foreground turns away from the sick person as he covers his nose with his hand. It is possible that he, too, is holding a pomander. In his other hand he is carrying a basket with glowing embers, used for burning aromatic herbs. In the Venetian version on the left, the doctor is flanked by two men with burning torches, which was also a proven method for dispelling miasmata. The author noted that 'air should be dried as much as possible, by a fire of oak wood or of well dried boughs of laurel, of myrtle, juniper and other odoriferous woods [to decrease transmission of the plague]'. A curious difference between the two woodcuts is the presence of older women in the Antwerp edition. They are the only ones not using any kind of protection because, according to 
medical beliefs at the time, their bodies had smaller pores making them less susceptible to foul air particles. ${ }^{40}$

\section{Stinking Corpses}

In the later seventeenth century, Daniel van Papenbroeck (Papebrochius) offered a casual remark in his extensive chronicle of the city of Antwerp:

Because it was customary to open graves and bury bodies daily, [the Church of Our Lady] was almost always a dangerous place for those feeling heavy or unwell; so much so that many people in less than perfect health were horrified of going to the parish churches, particularly pregnant women. It was therefore desirable to be able to open some windows here and there in good weather, to let some fresh air in..11

His comment leaves little to the imagination as regards the daily aroma in the city's cathedral. The most dreaded stench in the Antwerp church came from the many corpses. ${ }^{42}$ Between 1352 - the likely date the Gothic church was established - and the middle of the eighteenth century, thousands of people were buried under the slabs of the church (fig. 6). ${ }^{43}$ However, it remains unclear how often the floor was in fact dug up. According to Tony Oost, who led the archaeological site investigations of parts of the cathedral between 1987 and 1990, burials must have occurred regularly. ${ }^{44}$ A sample from the church accounts in the mid-sixteenth century shows a rather low number, namely between twenty-four and thirty-three burials inside the church (kerklijken) per year. ${ }^{45}$ However, a concession from 1535 proves that the church accounts may need to be taken with a pinch of salt. Two years after a major fire at the church, the powerful guild of Onze-Lieve-Vrouwe-Lof (Our Lady's Praise) obtained the concession that there would be no more 'funerals, masses of the seventh or thirtieth days, or memorial masses for any bodies on Sundays, holy days, or working days' in their chapel, unless there were at least three deceased in one day. They

40 Cited in Dimaio, Discepola, and Del Maestro, 'Il Fasciculo di Medicina', 190-191; Coppens, "For the Benefit”, 186-187. On medical theory, see Temkin, Galenism.

41 Papebrochius, Annales antverpienses, v, 344: 'Per easdem scalas itur ad ambulationem circumductam Basilicae toti, inter fenestras maiores peristyliumque maiorum columnarum; cuius rei minime contemnendus usus esset, si fenestrae praedictae aliqua sui parte possent aperiri, ad intromittendum idoneo tempore puriorem aerem, qui nunc, propter quotidianam recludendorum ad tumulanda cadavera sepulcrorum consuetudinem, fere semper gravis et male habentibus perniciosus est; ut multi non optime valentes horreant ideo ecclesias Parochiales subire, praesertim mulieres gravidae.'

42 Camporesi, Het onvergankelijke vlees, 109.

43 Some of the exhumed skeletons date back to the Romanesque church, according to personal information received from Tony Oost on 12 July 2020. On the change in mentality associated with the ban on burials within city limits, see Hendrickx, 'Het dode gevaar?', 33-34. Van 't Hul, 'Mag je eroverheen', contains some interesting information about early modern burials in the Northern Netherlands, although the author does not cite any sources: the preferred time of burial was apparently during the Sunday sermon.

44 Information received from Tony Oost, 26 February 2019 and 12 July 2020.

45 Antwerp, Kathedraalarchief Antwerpen (hereafter KAA), Registers Kerkfabriek, Rekeningen van de Kerkfabriek (hereafter RK) 14, 1546-1547, fols. 39r-4or: twenty-four kerklijken and twenty-six koorlijken; 15471548, fols. 27r-28r: thirty kerklijken; 1548-1549, fols. 33v-34r: thirty-three kerklijken. This means the number of kerklijken recorded by Prims is too low: Prims, 'Uit de kerkrekeningen', 109, 112, 114-116, 118, 122. 


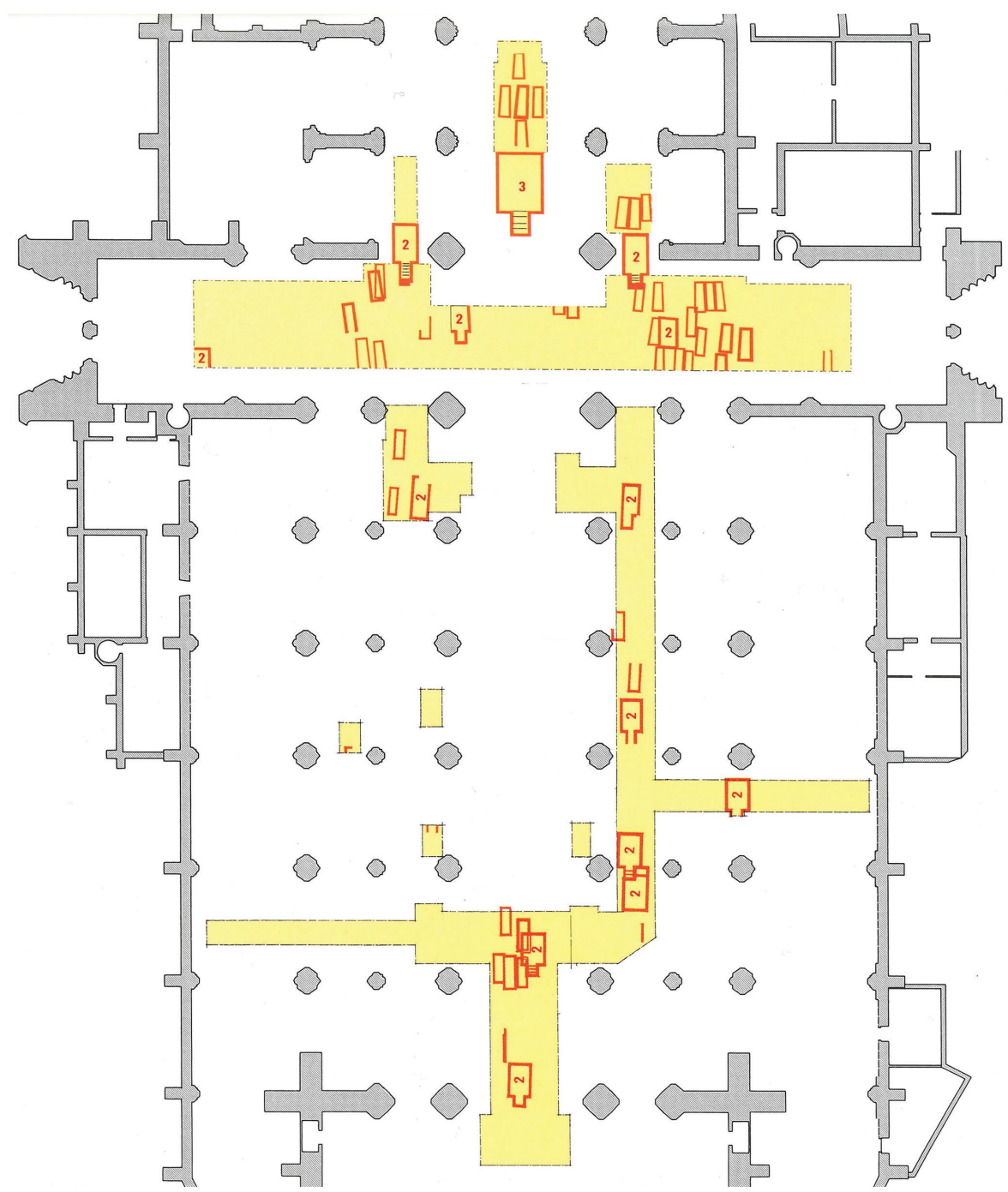

Fig. 6 Floor plan of the Antwerp Church of Our Lady, showing the archaeological excavations (yellow), single crypts (red), communal or family crypts (nos. 2), and the canons' crypt (no. 3), in: Oost et al., 'Archeologisch bodemonderzoek', 326 .

obtained this exemption after donating a significant sum of money towards the repair of the damaged church. ${ }^{46}$ Based on this source, it is clear that it was indeed common for

46 Cited in Persoons, De orgels en de Organisten, 156, on the basis of KAA, B.M.V. [Beata Maria Virgo], Agreemeent between chapter and masters of the brotherhood of Our Lady regarding funeral services, 1535: 'Uijtvaerden, sevenste, dertichste noch jaergetijden van eenighen lijcken op sondaghen heijlichdaighen noch werckdaighen'. 
multiple burials to take place per day, and it was probably impractical for the various religious organisations to grant access to their altars every time. When people expressed a preference for a burial location in their will, they would usually name a specific chapel, altar, or pew, or request to be buried in the vicinity of the pulpit or the choir. ${ }^{47}$ The most expensive location was the choir, since proximity to the Holy Sacrament was believed to promote the salvation of the soul. People settled for a plot in the cemetery only if burial inside the church was financially unattainable..$^{48}$

Space was at a premium due to the growing urban population, and especially so during times of sickness or war. Due to practical considerations, the same burial pit could be used for multiple bodies (stacking as many as eight) and pits were also extremely close together. ${ }^{49}$ The limited number of burial pits in the church were regularly cleared to make room for new bodies. In fact, the demand for new plots both within and without the church building was so high, graves were emptied and re-used before their previous occupants could fully decompose..$^{50}$ By 1582 St. Andrew's cemetery had become so badly overcrowded that the resulting 'heavy stench and infection' led to a ban on burying more bodies for several months. ${ }^{51}$ During epidemics, temporary measures were implemented, but burial within the city limits was never questioned..$^{52}$ For example, fear of contamination by miasmata was so great that viewing the body in church was no longer permitted. The burial took place immediately, even before the funeral service. Moreover, it was forbidden to bury anyone while a Mass was being celebrated at another location in the church. At the same time, large bonfires were lit in graveyards to dispel the foul air. To relieve the pressure on the traditional parish churchyards, supplementary cemeteries within the city walls could be consecrated, as was done by the canon priest Franciscus Donckers during the plague outbreak of $1571 . .^{53}$ Still, until the late eighteenth century, when Joseph II ordered all city churchyards in the Austrian Low Countries to be moved outside urban centres, the lack of burial space would remain a recurring problem. ${ }^{54}$

47 Oost et al., 'Archeologisch bodemonderzoek', 329; Prims, 'Uit de kerkrekeningen', 116, 120-122.

48 KAA, RK 14, 1547-1548, fols. 27r-28v. After kerklijken the revenue for schellijken was itemised (twenty-two in total, fols. $28 \mathrm{r}-28 \mathrm{v}$ ). The hierarchy was as follows: koorlijken (choir burial), kerklijken (church burial), and kerkhoflijken (cemetery burial). The cemetery burials were differentiated based on the location of the bier (vrouwlijk: near the statue of Our Lady) or based on the sound of the bells (schellijk, named after the schelle, ringing): Beghein, Kerkmuziek, consumptie en confessionalisering, 153; Hendrickx, 'Het dode gevaar?', 28; Vroom, De Onze-Lieve-Vrouwekerk, 39, 116, nt. 10.

49 Gravediggers used a coordinated system to create new burial pits, according to information received from Tony Oost on 12 July 2020. In the burial pits that were excavated underneath Saint Bavo's Cathedral, six to seven people were stacked on top of one another: Verstraete and Van Meer, '8oo skeletten gevonden'.

50 Only in the Green Cemetery the bones remained in the burial pits when new caskets were lowered. Older graves in the Church of Our Lady, the monasteries, daughter churches, and their graveyards were cleared regularly, and the skeletal remains stored in charnel vaults, such as the one under the choir of the Church of Our Lady: Oost, 'Over de gezonken kist', 48; Hendrickx, 'Het dode gevaar?', 29-30.

51 Cited in Hendrickx, 'Het dode gevaar?', 29: 'soo grooten stanck ende infectie'.

52 Craig Koslofsky did discern a shift from intra- to extramural burial in the sixteenth-century Holy Roman Empire, arguing this phenomenon was incited by both medical and Protestant sensibilities: Koslofsky, The Reformation of the Dead, 45-47.

53 Van Schevensteen, Documents, 99.

54 On the change in mentality associated with the ban on burials within city limits, see Hendrickx, 'Het dode gevaar?', 31-34. 
The stench was at its worst when a burial pit was left uncovered, or covered only with a thin layer of soil, in anticipation of the next funeral. Though these practices were strictly outlawed, compliance was clearly less than perfect. ${ }^{55}$ A document from 1638 sheds some light on one of the reasons why these ordinances were so frequently ignored. Gravediggers covered 'the dead bodies with so little soil, that it often resulted in a dreadful stench. They did this intentionally so that the owners of the burial plots would believe that the graves [in the church] needed to be cleared sooner. This carried no fixed fee, and so they could extort them to pay excessive prices. ${ }^{56}$ Apart from burial pits, the church also housed crypts: forty-seven individual crypts and fourteen shared ones, most of which were arranged haphazardly throughout the southern transept (fig. 6). These would also release a disgusting smell whenever they were opened to add a newly deceased family member. ${ }^{57}$ In the 1286 Rationale Divinorum Officiorum, which by the fifteenth century had become the most copied liturgical exposition in Western Europe, Durandus had good reason to advise readers to place burning incense in the tomb..$^{8}$ Church leaders purchased aromatics explicitly for this reason. Lighting candles and burning incense during funerals not only served as a symbol of virtue, transition, and rising prayers, but also as protection against wafts of miasmata. Durandus and others explained that these fragrant clouds protected bystanders from the risks of harmful odours. ${ }^{59}$ Gravediggers also carried strong aromatics and some bodies were buried with fragrant herbs. ${ }^{60}$

The scattering of fresh rushes and other plants on the floor in order to keep the foul-smelling filth at bay even developed into a fully-fledged religious festival in late medieval England: rush-bearing. ${ }^{61}$ Much ink has also been spilled about whether or not there is religious significance to the greenery appearing in many paintings from the Southern Netherlands. ${ }^{62}$ But specifically in terms of medicinal use, there are only rare instances where such a floral theme appears in the iconography of church interiors. The Leiden painter Aertgen Claesz. van Leyden elegantly exhibited the medicinal use of plants in his panel painting The Calling of Saint Anthony (c. 1530, fig. 7). The flowers and herbs scattered in the foreground were used to treat Saint Anthony's fire (ergotism) and the plague. ${ }^{63}$

55 Tony Oost helpfully remarked that leaving burial sites uncovered in anticipation of the next funeral was forbidden as early as the year 585 (Council of Macon, canon 17). See also Sapin, 'Architecture and Funerary Space', 40.

56 KAA, Capsa Dominorum, 14, Th. 35, cited in Hendrickx, 'Het dode gevaar?', 32: 'de doode lichaemen soo weynich met aerde, dat dickmaels grooten stanck veroorsaeckt [wordt], het welck door hun gedaen wordt met de intentie van de eygenaers der grafplaetsen soo veel te eerder te doen gelooven dat de graeven [in de kerk] moeten geruymt worden. Op welck geen taxaet sijnde sij als dan daer voor escessieve sommen sijn afpersende.'

57 Oost, 'Over de gezonken kist', 49; Mannaerts, De kathedraal, 191.

58 Durand, Rationale, 22. Holy water was used to drive out demons, and incense to dispel the smell of death: Atchley, A History of the Use of Incense, 204.

59 Baum, 'From Incense', 328.

60 Classen, Howes, and Synnott, Aroma, 53, 61.

61 Some aristocratic households in England even had fresh rushes delivered daily: George, 'Rushbearing', 17-18; Milner, The Senses, 315.

62 Sillasoo, 'Medieval Plant Depictions', 61, 68.

63 Bruyn, 'Twee St. Antonius-panelen', 58-61; Filedt-Kok, Halsema-Kubes, and Kloek (eds.), Kunst voor de beeldenstorm, 161; Boelaert, De medische renaissance, 103-104. 


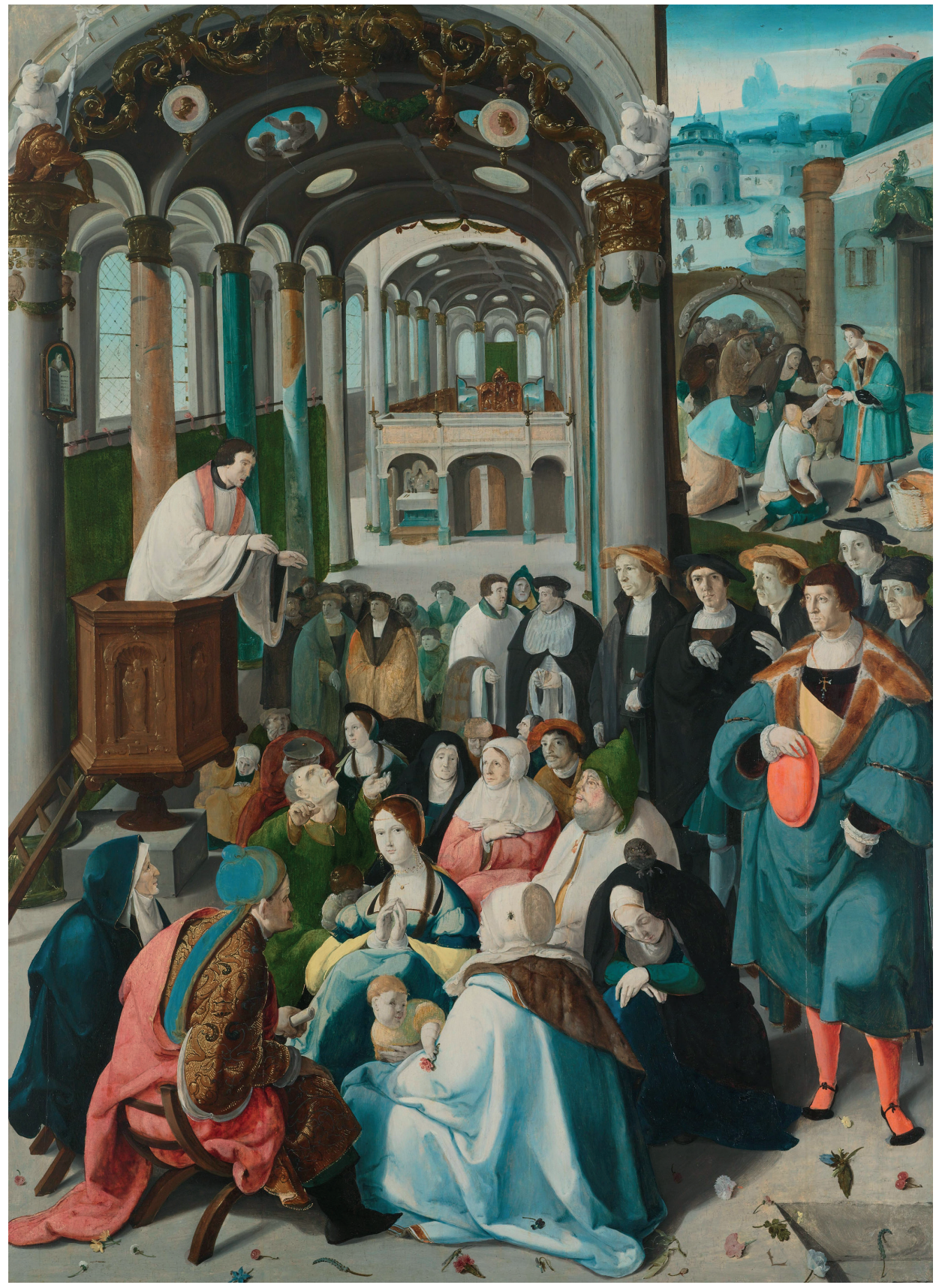

Fig. 7 Aertgen Claesz van Leyden, The Calling of St Antony, c. 1530, oil on panel, 132,5 $\times 96,3 \mathrm{~cm}$, Amsterdam, Rijksmuseum. 
In the background, Saint Anthony, in contemporary garb, distributes bread to a group of cripples who may be suffering from this affliction. ${ }^{64}$ Ergotism patients often needed assistance to walk due to their rotting feet. The painting may have been displayed either in Saint Anthony's hospital in Leiden, or as part of the altarpiece of the eponymous guild. ${ }^{65}$

Finally, the geographical location of the church relative to the topography of Antwerp affected its palette of odours. Among others, the nearby Churchyard of Our Lady (Green Cemetery), was the source of significant olfactory peril. This busy location was used by various industries as a marketplace or place of work. Church officials allowed furriers, glovers, and mercers to set up shop during annual fairs. This lasted until 1468, when Charles the Bold decided to put an end to the 'evil sins and adultery and other unseemly and dishonourable crimes, leading to death and bloodshed' that occurred so close to the church at market times. From then on, market stalls moved outside of the sanctuary, but without depriving the church authorities of the income generated by renting out the pitches. ${ }^{66}$ However, the Green Cemetery remained a popular spot year-round for retail and recreation throughout the early modern period. ${ }^{67}$ It goes without saying that the furriers, glovers, and mercers did not always leave the churchyard in pristine condition. The Antwerp customary law (coren) therefore stipulated fines for 'leaving any kind of rubbish on the marketplace, or on the cemetery of Our Lady, or on the fish market or on anyone's doorstep on the street'. ${ }^{68}$ When the wind was unfavourable, moreover, the smell of rotting carcasses from the nearby butchers' quarter - located just 150 meters away - wafted into the church, while fly-tippers frequently dumped meat waste in the nearby streets or even in the churchyard. ${ }^{69}$ As a result, the muddy tracks left by worshippers on the church floor were an unpleasant mixture of dirt, rubbish, stale water, congealed blood, and faeces.

\section{Purifying Incense}

In analogy with the method for dispelling miasmata, the virtuous aroma of incense suggested spiritual purification. ${ }^{70}$ Incense was used at many different events, including the consecration of new churches, burial grounds, bells, altars, vasa sacra, bishops, and the

64 Scholten, 'Technische aspecten', 62.

65 Bruyn, 'Twee St. Antonius-panelen', 63.

66 Un mercante di Milano, 75-76: 'Quade sunden en overspel ende ander mesdaden ontamelic ende oneerbaerlick totten doot ende bloetstortinge.'

67 Complaints were registered throughout the sixteenth century: Génard (ed.), 'Index der gebodboeken', 132 (ball games), 134-135 (ball games and market stalls), 185 (games), 209 (games), 259 (peltiers, bleaching, tooth pullers, quacks, and games), 267 (assembly, fighting), 275 (market stalls); Poulussen, Van burenlast, 159. See also Alexandre-Bidon, 'Het kerkhof', 244-251.

68 Dit sijn de coren, 41-42, art. 109: 'Eenegherande vulnesse op die maret leide, ochte op OnserVrouwen kerchof, ochte op die vischmarct, ochte vor yement anders anthoeft op der straten.'

69 It was only in 1552 that it became mandatory to transport meat waste in closed barrels to the Pensgat by the Scheldt: Poulussen, Van burenlast, 98-99, 108, and 208 (maps 1 and 2).

70 This belief is expressed for instance by Durandus and in a blessing from the 1560 Milanese missal: Durand, Rationale, 121; Atchley, A History of the Use of Incense, 132-133. 
holy chrism, the blessing of holy anointing oils, and when officiating weddings. ${ }^{71}$ What all these circumstances have in common is a change in spiritual status: by censing the route of a procession ahead of the passage of the Sacrament, a dirt road was transformed into a temporal religious space, worthy of the holiest. ${ }^{72}$ But spiritual and physical purity were two sides of the same coin. Both incense and storax (a balsamic, fragrant resin) were popular disinfectants as well as a protection against the rancid smell of jam-packed parishioners and pilgrims..$^{73}$ The liturgical scholar Cuthbert Atchley mentions a common blessing which utilises incense specifically for its air-purifying qualities: 'May the Lord bless this incense for the removal of every harmful stench, and kindle it for the perfume of its sweetness. ${ }^{74}$ Accordingly, Atchley believes that censing people halfway through the celebration of Mass was originally done with the intent to disinfect. By that time, poorly ventilated church spaces would have become musty with the body odour of the gathered worshippers. ${ }^{75}$

The purifying powers of incense also found their way into private devotion. Prayer and contemplation fortified the devout spirit, resulting in spiritual sweetness, and prayer beads often stimulated a fragrant experience. Beads made from amber would emit a pinelike smell when in contact with a warm body. The scent not only pervaded the space around the devotee, but also clung to their fingers after prayer. By the middle of the sixteenth century, the clergy increasingly made use of raw amber by burning it during Mass. Throughout Western Europe, the smell became strongly associated with church buildings and religious ceremonies. ${ }^{76}$ Even the elaborately worked ornaments or tiny carvings that decorated the end of the string of beads were capable of touching both nose and spirit. An often-used pendant for this purpose was the pomander, a round shaped object containing perfumes. The aromatic dimension of these objects was a continuation of the late medieval tradition of including copious garden and floral metaphors in vernacular prayers. Those were after all the meditative prayers that were being recited with the aid of prayer beads. ${ }^{77}$

Beads as well as pendants existed in all manner of shapes and materials, ranging from luxurious golden, silver, or amber showpieces to cheaper tin, glass, or wooden versions. Recipes were circulated for making one's own sweet-smelling paternosters (welrieckende paternosteren). The Batement van recepten contained instructions for using simple ingredients at home. The dough was a mix of dark soil, tragacanth (a sweet white gum), storax, calaminta (a type of mint), cloves, laudanum, cinnamon, and sandael cytrin (white or yellow sandalwood). Both storax and sandalwood have incense-like aromas, clearly

\footnotetext{
71 Herrera, 'Holy Smoke'.

72 These rites did not exclusively make use of incense; candles and other objects also contributed to the change in status: Bossuyt, Vroegstedelijke devotiebeleving, 37-40.

73 Incense was also used for medical reasons. See for instance De Lobel, Kruydtboeck, II, 182, and Den Sack der Consten. In Riddle's corpus of late medieval Pestschriften, incense is listed as an ingredient in twelve of the thirty-one recipes: Riddle, 'Pomum Ambrae', 119. See also Corbin, The Foul and the Fragrant, 65; Milner, The Senses, 109.

74 Atchley, A History of the Use of Incense, 203; Martène, De antiquis ecclesioe ritibus, I, 191.

75 Atchley, A History of the Use of Incense, 209.

76 King, 'The Beads', 168-169.

77 Falkenburg, 'Toys for the Soul', 34-36.
} 
suggesting an association with the church building. ${ }^{78}$ In short, the fragrances released when using different types of prayer beads symbolised virtue and manifested both internally (on a spiritual level) and externally (in the surrounding space and on fingertips).

\section{Conclusion}

The memento mori pendants with their abraded noses are only one element of the olfactory dimension penetrating sixteenth-century lived religion. In late medieval Antwerp, there was a strong interaction between externally perceived body odour and a person's inner sweetness. Believers resorted to ritual actions and concrete practices that were smallscale reflections of prevailing medical theories and philosophies. The same wholesome or harmful odours that regulated physical health also applied to one's purity of spirit. As sinners stank both physically and spiritually, prayer could, alongside a spiritual sweetness, effect a sweet aroma. As such, the interconnectedness of physiology and religious experience adds new layers of interpretation to long known objects and rituals in late medieval Christianity, and to the olfactory dimensions behind death, disease, and burial within one particularly illustrative Antwerp church.

\section{Bibliography}

\section{Archival and Manuscript Sources}

Antwerp, Erfgoedbibliotheek Hendrik Conscience, 817449, Petrus Henricus Goos, Encronologium episcoporum, decanorum et canonicorum Cathedralis Basilicae Marianae Antverpiensis, 2 vols., 1695-1719.

Antwerp, Kathedraalarchief Antwerpen, Registers Kerkfabriek, Rekeningen van de Kerkfabriek 14, 1541-1550.

St. Gallen, Stiftsbibliothek, Cod. Sang. 547, Petrus Comestor, Historia Scholastica, 1175-1225.

\section{Printed Sources}

Albert, Jean-Pierre, Odeurs de sainteté. La mythologie chrétienne des aromates (Paris 1990).

Alexandre-Bidon, Danièle, 'Het kerkhof, verblijfplaats van de doden... en de levenden (veertiende-vijftiende eeuw)', in Sophie Balace and Alexandra De Poorter (eds.), Tussen hemel en hel. Sterven in de middeleeuwen, 600-1600 (Brussels 2010) 244-251.

Atchley, E.G. Cuthbert F., A History of the Use of Incense in Divine Worship (London 1909).

Baert, Barbara, Late Medieval Enclosed Gardens of the Low Countries. Contributions to Gender and Artistic Expression (Leuven 2015).

Baert, Barbara, and Hannah Iterbeke, 'Revisiting the Enclosed Gardens of the Low Countries (Fifteenth century onwards). Gender, Textile, and the Intimate Space as Horticulture', Textile. Journal of Cloth and Culture $15(2017 / 1)$ 2-33.

78 For a recipe compilation translated from the Italian that was disseminated throughout Western Europe during the sixteenth century, see Braekman (ed.), Dat batement, 7, 11, 89-90. See also Falkenburg, 'Toys for the Soul', 36-37, 39. The selection of certain herbs was based on a mix of the symbolic value of their scent and their actual healing properties: Falkenburg, 'Toys for the Soul', 43. In addition, amber was sold in apothecaries, applied to the skin to dispel miasmata, and burned to fight the plague: King, 'The Beads', 166-167, 170. 
Braekman, Willy L. (ed.), Dat batement van recepten. Een secreetboek uit de zestiende eeuw (Brussels 1990).

Baum, Jacob M., Sensory Perception, Religious Ritual and Reformation in Germany, 1428-1564. PhD diss., University of Illinois, 2013.

Baum, Jacob M., 'From Incense to Idolatry. The Reformation of Olfaction in Late Medieval German Ritual', Sixteenth Century Journal $44(2013 / 2)$ 323-344.

Beghein, Stefanie, Kerkmuziek, consumptie en confessionalisering. Het muziekleven aan Antwerpse parochiekerken c. 1585-1797 (Antwerp 2014).

Bijns, Anna, Refereinen. Willem Lodewijk Van Helten (ed.) (Rotterdam 1875).

Blancou, J., 'History of Disinfection from Early Times until the End of the 18th Century', Revue Scientifique et Technique 14 (1995/1) 31-39.

Boelaert, Johan R., De medische renaissance van de twaalfde eeuw. Zoektocht naar kennis en vernieuwing in de ziekenzorg (Antwerp 2014).

Bossuyt, Stijn, Vroegstedelijke devotiebeleving in middeleeuws Vlaanderen (10oo-1350). Een vergelijkend onderzoek van enkele bedehuizen in Brugge, Rijsel en Sint-Omaars. PhD diss., KU Leuven, 2007.

Bruyn, Josua, 'Twee St. Antonius-panelen en andere werken van Aertgen Van Leyden', Nederlands Kunsthistorisch jaarboek 11 (1960) 36-119.

Bynum, Caroline Walker, Christian Materiality. An Essay on Religion in Late Medieval Europe (Brooklyn 2011).

Camporesi, Piero, Het onvergankelijke vlees. Heil en heling in de middeleeuwen en vroeg-moderne tijd (Nijmegen 1994).

Carter, Michael, 'Memento Mori. Let's Talk About Death', English Heritage, http://blog.english-heritage.org. uk/momento-mori-lets-talk-about-death/ (Accessed on 19 February 2020).

Classen, Constance, 'The Odor of the Other. Olfactory Symbolism and Cultural Categories', Ethos 20 (1992/2) 133-166.

Classen, Constance, David Howes, and Anthony Synnott, Aroma. The Cultural History of Smell (London 1994).

Classen, Constance, 'The Breath of God. Sacred Histories of Scent', in Jim Drobnick (ed.), The Smell Culture Reader (Oxford 2006) 375-390.

Coppens, Christian, "'For the Benefit of Ordinary People". The Dutch Translation of the Fasciculus medicinae, Antwerp 1512', Quaerendo 39 (2009) 168-205.

Corbin, Alain, The Foul and the Fragrant. Odor and the French Social Imagination (London 1994).

De Commer, P., 'Hygiëne en gezondheidszorg in de Antwerpse gezondheidsinstellingen tijdens het Ancien Régime', in Petra Maclot and Werner Pottier (eds.), 'N propere tijd!? Onleefbaar Antwerpen thuis en op straat 1500-1800 (Antwerp 1988) 37-44.

De Gelder, Anouk, 'In God's ban geslagen?' Lepralijders van de 13e-tot vroege 16e-eeuw in Vlaanderen, een studie naar infectiebesef. MA thesis, University of Ghent, 2014.

De Ketham, Johannes, The Fasciculus Medicinae of Johannes De Ketham Alemanus. Facsimile of the First (Venetian) Edition of 1491, Luke Demaitre trans. (Birmingham 1988).

De Keyser, Joey, De visie van vreemdelingen op de Zuidelijke Nederlanden in de late middeleeuwen en de renaissance. MA thesis, University of Ghent, 2007.

De Lobel, Matthias, Kruydtboeck oft Beschrijuinghe van allerley Ghewassen, Kruyderen, Hesteren, ende Gheboomten, 2 vols. (Antwerp: Christoffel Plantijn, 1581).

Den Sack der Consten (Antwerp: Jacob van Liesvelt, 1528).

Dit sijn de coren van der stad Antwerpen (Ghent 1852).

Duffy, Eamon, The Stripping of the Altars. Traditional Religion in England 1400-1580 (New Haven 2005).

Dugan, Holly, The Ephemeral History of Perfume. Scent and Sense in Early Modern England (Baltimore 2011).

Dimaio, Salvatore, Federico Discepola, and Rolando F. Del Maestro, 'Il Fasciculo di Medicina of 1493. Medical Culture through the Eyes of the Artist', Neurosurgery 58 (2006/1) 187-196.

Durand, Willem, Rationale, Book 4. On the Mass and each action pertaining to it. Timothy M. Thibodeau (ed.) (Turnhout 2013). 
Erasmus, Desiderius, Annotationes, of aanteekeningen op 't Nieuwe Testament (Amsterdam: Jan Rieuwertsz., 1663).

Falkenburg, Reindert L., The Fruit of Devotion. Mysticism and the Imagery of Love in Flemish Paintings of the Virgin and Child, 1450-1550 (Amsterdam 1994).

Falkenburg, Reindert, 'Toys for the Soul. Prayer-Nuts and Pomanders in Late Medieval Devotion', in Reindert Falkenburg and Frits Scholten (eds.), A Sense of Heaven. 16th Century Boxwood Carvings for Private Devotion (Leeds 1999) 32-47.

Filedt-Kok, Jan Piet, Willy Halsema-Kubes, and Wouter Kloek (eds.), Kunst voor de beeldenstorm. Noordnederlandse kunst 1525-1580 (The Hague 1986).

Fortescue, Adrian, 'Liturgy of the Mass', in Charles G. Herbermann et al. (eds.), The Catholic Encyclopedia, 15 vols. (New York 1907-1912), IX, via https://www.newadvent.org/cathen/o979ob.htm (Accessed on 22 January 2021).

Gauthier, Catherine, L'encens et le luminaire dans le haut Moyen Âge occidental. Liturgie et pratiques dévotionnelles. PhD diss., Vrije Universiteit Brussels, 2008.

Génard, Pierre (ed.), 'Index der gebodboeken', Antwerpsch Archievenblad 1 (1864/1) 120-464.

George, David, 'Rushbearing. A Forgotten British Custom', in Alexandra F. Johnston and Wim Hüsken (eds.), English Parish Drama (Amsterdam 1996) 17-30.

'Gothic Ivories', http://gothicivories.courtauld.ac.uk (Accessed on 4 May 2021).

Guicciardini, Lodovico, Beschrijvinghe van alle de Neder-landen. Petrus Montanus (ed.), (Haarlem 1979, facsimile ed. 1612).

Hendrickx, J., 'Het dode gevaar? Begraven en hygiëne te Antwerpen van de 16de tot de 18de eeuw', in Petra Maclot and Werner Pottier (eds.), 'N propere tijd!? Onleefbaar Antwerpen thuis en op straat 1500-1800 (Antwerp 1988) 26-36.

Herrera, Matthew D., 'Holy Smoke. The Use of Incense in the Catholic Church', Adoremus https:// adoremus.org/2012/02/holy-smoke-the-use-of-incense-in-the-catholic-church/ (Accessed on 22 January 2019).

Jansen-Sieben, Ria, 'Ziektebeeld en behandeling in de Middelnederlandse medische literatuur', in Marleen Forrier, Walter De Keyzer, and Michel Van der Eycken (eds.), Lepra in de Nederlanden (12de-18de eeuw) (Brussels 1989) 34-43.

King, Rachel, “"The Beads with Which We Pray Are Made from It”. Devotional Ambers in Early Modern Italy', in Wietse de Boer and Christine Göttler (eds.), Religion and the Senses in Early Modern Europe (Leiden 2013) 153-175.

Largey, Gale Peter, and David Rodney Watson, 'The Sociology of Odors', American Journal of Sociology 77 (1972/6) 1021-1034.

Lowagie, Hannes, Par Desperacion. Zelfmoord in het graafschap Vlaanderen tijdens de Bourgondische periode (1385-1500). Een sociologische aanpak. MA thesis, University of Ghent, 2007.

Mannaerts, Rudi, De kathedraal. De Onze-Lieve-Vrouwekathedraal van Antwerpen, een openbaring (Antwerp 2016).

Marinus, Marie Juliette, De contrareformatie te Antwerpen (1585-1676). Kerkelijk leven in een grootstad (Brussels 1995).

Marnef, Guido, Antwerpen in de tijd van de Reformatie. Ondergronds protestantisme in een handelsmetropool, 1550-1577 (Amsterdam 1996).

Martène, Edmond, De antiquis ecclesice ritibus editio secunda, 4 vols. (Antwerp: Joannis Baptistæ de la Bry, 1736-1738).

McBride, Nuri, 'The Odour of Sanctity. When the Dead Smell Divine', The Order of the Good Death, http:// www.orderofthegooddeath.com/odour-sanctity-dead-smell-divine (Accessed on 15 February 2019).

'Memento Mori Pendant', English Heritage, https://sketchfab.com/3d-models/memento-mori-pendant-fd4c33e8bd524bb7a21fa61367918f9c (Accessed on 19 February 2020).

Mertens, Frans Hendrik, and Karel Lodewijk Torfs, Geschiedenis van Antwerpen, sedert de stichting der stad tot onze tyden, 8 vols. (Antwerp 1845-1853).

Middelnederlandsch Woordenboek online, http://ivdnt.org (Accessed on 5 June 2020). 
Milner, Matthew, The Senses and the English Reformation (London 2011).

Nieuwdorp, Hans, 'Het kunstpatrimonium. De middeleeuwen', in Willem Aerts (ed.), De Onze-Lieve-Vrouwekathedraal van Antwerpen (Antwerp 1993) 161-176.

Oost, Tony, et al., 'Archeologisch bodemonderzoek tijdens de restauratiewerken', in Willem Aerts (ed.), De Onze-Lieve-Vrouwekathedraal van Antwerpen (Antwerp 1993) 307-338.

Oost, Tony, 'Over de gezonken kist gebogen. Aspecten van funeraire archeologie in Antwerpen', Provinciale Commissie voor Geschiedenis en Volkskunde (1997) 45-56.

Papebrochius, Daniël, Annales antverpienses ab urbe condita ad annum M.DCC. Collecti ex ipsius Civitatis monumentis publicis privatisque Latinae ac patriae linguae. François Henri Mertens and Joseph-Ernest Buschmann (eds.) 5 vols. (Antwerp 1845-1848).

Perkinson, Stephen, 'The Ivory Mirror', in Stephen Perkinson (ed.), The Ivory Mirror. The Art of Mortality in Renaissance Europe (New Haven 2017) 13-80.

Persoons, Guido, De orgels en de organisten van de Onze Lieve Vrouwkerk te Antwerpen van 1500 tot 1650 (Brussels 1981).

Pfeifer, Michael, Der Weihrauch. Geschichte, Bedeutung, Verwendung (Regensburg 1997).

Philippen, Lodewijk, Le culte de Notre-Dame op 't Stocxken à Anvers, 1474-1580 (Antwerp 1925).

Poulussen, Peter, Van burenlast tot milieuhinder. Het stedelijk leefmilieu, 1500-180o (Kapellen 1987).

Prims, Floris, Geschiedenis van Antwerpen, 10 vols. (Antwerp 1927-1949).

Prims, Floris, 'Uit de kerkrekeningen van O.L.V. van Antwerpen', Bijdragen tot de geschiedenis 30 (1939) 101-122.

Put, Eddy, and Craig Harline, Verloren schapen, schurftige herders. De helse dagen van bisschop Mathias Hovius (1542-1620) (Leuven 2002).

Riddle, John M., 'Pomum Ambrae. Amber and Ambergris in Plague Remedies', Sudhoffs Archiv für Geschichte der Medizin und der Naturwissenschaften 48 (1964/2) 111-122.

Rombough, Julia, 'Through Thick and Thin. Air Quality and the Senses in Early Modern Italy'. Conference paper, RSA Toronto, 18 March 2019.

Rubens, R., 'Wijzigende concepten in het ontstaan van de infectieuze aandoeningen', in Robrecht Van Hee (ed.), Ziek of gezond ten tijde van Keizer Karel. Vesalius en de gezondheidszorg in de 16e eeuw (Ghent 2000) 57-72.

Sapin, Christian, 'Architecture and Funerary Space in the Early Middle Ages', in Catherine E. Karkov, Kelley M. Wickham-Crowley, and Bailey K. Young (eds.), Spaces of the Living and the Dead. An Archaeological Dialogue (Oxford 1999) 39-60.

Scholten, Frits, 'Technische aspecten van de kerkprediking en twee andere werken uit de Aertgen van Leyden-groep', Nederlands Kunsthistorisch Jaarboek 37 (1986) 53-74.

Sillasoo, Ülle, 'Medieval Plant Depictions as a Source for Archaeobotanical Research', Vegetation History and Archaeobotany 16 (2006/1) 61-70.

Sullivan, Erin, and Andrew Wear, 'Materiality, Nature and the Body', in Catherine Richardson, Tara Hamling, and David Gaimster (eds.), The Routledge Handbook of Material Culture in Early Modern Europe (London 2016) 141-157.

Suykerbuyk, Ruben, The Matter of Piety. Material Culture in Zoutleeuw's Church of Saint Leonard (c. 14501620), 2 vols. PhD diss., University of Ghent, 2017.

Synnott, Anthony, The Body Social. Symbolism, Self and Society (London 1993).

Temkin, Owsei, Galenism. Rise and Decline of a Medical Philosophy (London 1973).

Thomson, John A.F., 'Wyche, Richard', Oxford Dictionary of National Biography, https://doi.org/10.1093/ ref:odnb/50263 (Accessed on 21 February 2020).

Un mercante di Milano in Europa. Diario di viaggio del primo Cinquecento. Luigi Monga (ed.) (Milan 1985).

Vandenbroeck, Paul (ed.), Hooglied. De beeldwereld van religieuze vrouwen in de Zuidelijke Nederlanden, vanaf de 13de eeuw (Brussels 1994).

Van Den Nieuwenhuizen, Jos, Kapelaniewezen en kapelanen te Antwerpen van de oorsprong tot $1477 . \mathrm{PhD}$ diss., KU Leuven, 1963. 
Soen, Violet, and Anne-Laure Van Bruaene, 'Sacrale ruimtes in de vroegmoderne Nederlanden. Perspectieven en dwarsverbanden', in Liesbeth Geevers and Violet Soen (eds.), Sacrale ruimte in de vroegmoderne Nederlanden (Leuven 2017) 7-28.

Van Den Nieuwenhuizen, Jos, 'De koralen, de zangers en de zangmeesters van de Antwerpse O.-L.-Vrouwekerk tijdens de $15 \mathrm{e}$ eeuw', Gouden Jubileum Gedenkboek ter gelegenheid van de viering van 50 jaar heropgericht knapenkoor van de Onze-Lieve-Vrouwekathedraal te Antwerpen (1978) 29-72.

Van Dijck, Maarten, De pacificering van de Europese samenleving. Repressie, gedragspatronen en verstedelijking in Brabant tijdens de lange zestiende eeuw. PhD diss., University of Antwerp, 2007.

Van Schevensteen, A.F.C., Documents pour servir à létude des maladies pestilentielles dans le marquisat d'Anvers (Brussels 1931).

Van't Hul, J., 'Mag je eroverheen lopen of niet?', Reformatorisch Dagblad, 27 October 1995.

Verbeek, Caro, and Cretien Van Campen, 'Inhaling Memories. Smell and Taste Memories in Art, Science, and Practice, The Senses and Society 8 (2013/2) 133-148.

Verstraete, Alexander, and Anke Van Meer, '8oo skeletten gevonden onder Sint-Baafskathedraal in Gent', VRT NWS, 5 November 2019.

Vroom, Willem H., De Onze-Lieve-Vrouwekerk te Antwerpen. De financiering van de bouw tot de Beeldenstorm (Antwerp 1983).

Woolgar, Chris, The Senses in Late Medieval England (New Haven 2006).

Woolgar, Chris, 'The Medieval Senses were Transmitters as much as Receivers', Brewminate https://brewminate.com/the-medieval-senses-were-transmitters-as-much-as-receivers/ (Accessed on 9 September 2019). 